\title{
Perbaikan Sistem Pergudangan pada Perusahaan Distributor dengan Software Tecnomatix
}

\author{
Kelvin $^{1}$ \\ ${ }^{1}$ Departemen Teknik Industri, Sekolah Tinggi Teknik Surabaya \\ Email: kelvin@stts.edu
}

\begin{abstract}
Abstrak- Sebuah perusahaan distributor memiliki fungsi utama yaitu memproses produk yang masuk untuk disimpan dei dalam gudang serta menyalurkan produk dari gudang ke konsumen. Jumlah produk yang beraneka ragam serta permintaan yang berubah setiap waktu seringkali menjadi permasalahan utama dalam sistem pergudangan. Hal ini juga yang dialami oleh sebuah perusahaan distributor yang bergerak dalam bidang produk makanan di Sidoarjo. Perusahaan memiliki permasalahan dalam mengatur sistem pergudangan yang efisien. Proses penerimaan dan pengiriman yang terus berlangsung dalam jumlah besar dengan variansi produk yang sangat banyak membuat proses pergudangan menjadi kacau dan tidak sesuai dengan prosedur yang ada sehingga tingkat efisiensi proses menjadi menurun. Berdasarkan analisis hal-hal yang perlu mendapat perhatian adalah buffer zone, proses pencatatan barang, material handling dan masalah ruang kerja.

Berdasarkan prinsip pergudangan dan mengacu metode Activity Relationship Chart didapatkan perbaikan berupa perubahan tata letak buffer zone, perbaikan SOP pencatatan serta pengkodean barang, dan penambahan alat material handling. Dengan bantuan software Tecnomatix dapat disimulasikan dan didapatkan hasil waktu proses sebelum perbaikan pada bagian penerimaan adalah 5 menit 32 detik dan pada bagian pengiriman adalah 3 menit 42 detik. Setelah dilakukan perbaikan efisiensi proses meningkat terlihat dari waktu proses yang semakin cepat yaitu, pada bagian penerimaan menjadi 2 menit 53 detik dan pada bagian pengiriman menjadi 2 menit 7 detik.
\end{abstract}

Kata Kunci-Sistem Pergudangan, Tecnomatix

\section{Pendahuluan}

S ebuah perusahaan distributor di Sidoarjo bergerak di bidang distribusi bahan kebutuhan pokok masyarakat. Produk yang didistribusikan antara lain makanan kaleng, susu, minuman kaleng, sirup, permen dan berbagai produk lainnya dengan jumlah total produk yang ditangani lebih dari 100 varian. Proses utama yang dilakukan perusahaan distribusi adalah proses penerimaan barang dimana barang dikirim dari produsen dan disimpan di gudang distribusi, serta proses pengiriman dimana barang yang telah disimpan dikirim sesuai permintaan kepada konsumen. Dalam menjalankan proses ini, perusahaan memiliki gudang dengan luas 1500 meter persegi dan sudah memiliki standar prosedur yang harus dijalakan untuk memastikan produk yang diterima dan disalurkan sesuai. Namun, dalam pelaksanaannya banyak permasalahan yang terjadi antara lain: banyak produk yang tidak diletakkan pada tempat yang seharusnya, penataan produk yang tidak sesuai sehingga menyebabkan proses pencarian produk menjadi sulit, buffer zone atau area pengecekan yang tidak mencukupi serta penempatan yang tidak sesuai sehingga pengawasan terhadap produk menjadi berkurang. Masalah-masalah inilah yang menyebabkan tingkat efisiensi proses penerimaan dan pengiriman menjadi menurun.

Untuk meningkatkan efisiensi proses penerimaan dan pengiriman pada perusahaan perlu dilakukan perbaikan terutama perbaikan dalam hal sistem alur proses pergudangan sehingga sesuai dengan standar sistem pergudangan salah satunya dengan menggunakan metode Activity Relationship Chart (ARC) untuk mengetahui tingkat hubungan antar departemen serta mengukur waktu proses sebagai acuan efisiensi dengan menggunakan software Tecnomatix.

Keunggulan dalam penelitian ini adalah dengan penggunaan software Tecnomatix, dimana software Tecnomatix dari PLM Siemens merupakan software yang sangat canggih dan detail untuk mensimulasikan gerakan, dan interaksi antara manusia dan mesin dalam sebuah area kerja dengan format 3 dimensi. Selain itu, software ini dapat memberikan report berupa waktu, kesalahan gerakan, hingga tingkat kelelahan pekerja. Banyak penelitian sebelumnya yang telah membahas tentang perbaikan sistem pergudangan namun, penelitian hanya terfokus pada penataan ulang gudang. Dalam penelitian ini, akan memanfaatkan software Tecnomatix untuk melakukan simulasi perbaikan untuk mendapatkan hasil yang lebih nyata dari perbaikan yang telah dilakukan.

\section{Rumusan MaSAlah DAN TUJUAN PENELITIAN}

Rumusan masalah dalam penelitian ini adalah bagaimana merancang sistem pergudangan yang lebih efisien dan sesuai dengan standar pergudangan. Sedangkan, tujuan penelitian berdasarkan rumusan masalah tersebut adalah sebagai berikut:

1. Merancang sistem pergudangan yang lebih efisien.

2. Menghitung waktu proses setelah perbaikan dengan menggunakan software Tecnomatix.

\section{LANDASAN TEORI}

\section{A. Sistem Pergudangan}

Gudang adalah tempat yang dibebani tugas untuk 
menyimpan barang atau produk yang akan dipergunakan dalam hingga barang atau produk tersebut dibutuhkan[1]. Berdasarkan definisi tersebut dapat diketahui bahwa gudang merupakan tempat penyimpanan produk sementara. Fungsi gudang tidak hanya terbatas sebagai tempat penyimpanan. Berikut adalah fungsi gudang menurut Tompkins[2]:

a. Penerimaan

b. Inspeksi

c. Pengepakan ulang

d. Pemindahan produk

e. Penyimpanan

f. Pemenuhan permintaan

g. Sortir produk

h. Pengepakan dan pengiriman

i. Pengisian stok

Dari berbagai fungsi gudang tersebut oleh sebab itu perencanaan gudang yang baik perlu dilakukan. Berikut adalah berbagai tujuan perencanaan tata letak gudang menurut Tompkins[2]:

a. Utilisasi ruang yang lebih efektif.

b. Menyediakan material handling yang lebih efisien.

c. Meminimumkan biaya penyimpanan sementara untuk menyediakan tingkat pelayanan yang dibutuhkan.

d. Menyediakan fleksibilitas yang maksimum.

e. Menyediakan good housekeeping.

\section{B. Systematic Layout Planning (SLP)}

SLP merupakan metode untuk mengefisiensikan aliran produk dengan mengacu pada tingkat kedekatan antar unit departemen pada fasilitas yang akan dirancang[3]. Adapun tahapan yang harus dilakukan pada metode SLP adalah sebagai berikut:

1. Pengumpulan data masukan dan aktivitas

Hal pertama yang dilakukan adalah mengumpulkan informasi yang berkaitan dengan aktivitas gudang, seperti aliran produk dan urutan proses secara keseluruhan.

2. Analisis aliran material dan aktivitas operasional

Berdasarkan data masukan pada tahap sebelumnya dilakukan analisis berdasarkan aliran produk dan aktivitas tiap departemen agar diketahui aliran yang sesuai dan permasalahan yang dihadapi dalam proses perpindahan produk.

3. Activity Relationship Chart (ARC)

ARC bisa digunakan untuk menganalisa suatu layout dengan melihat sisi kualitatifnya, dan melihat hubungan keterkaitan antar bagian dari suatu pabrik, dan hal ini dilakukan dengan menganalisa pemindahan material dengan aspek kuantitatif (material handling cost)[4].

Dalam menggambarkan derajat kedektan hubungan antar seluruh kegiatan Activity Relationship Chart menggunakan simbol-simbol A, E, I, O, U dan X yaitu:
A: Hubungan bersifat mutlak
E: Hubungan bersifat sangat penting
I: Hubungan bersifat cukup penting
$\mathrm{O}:$ Hubungan bersifat biasa-biasa saja
U: Hubungan yang tidak diinginkan
$\mathrm{X}$ : Hubungan yang sangat tidak diinginkan
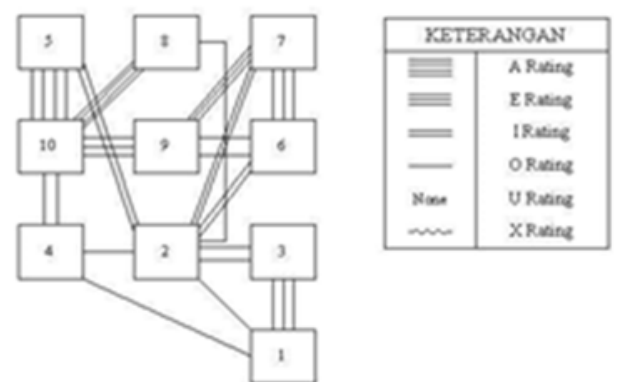

Gambar. 1. Activity Relationship Chart[5]

\section{Activity Relationship Diagram (ARD)}

ARD merupakan kombinasi antara aliran produk dengan keterkaitan antar departemen dalam pertimbangan penentuan layout berdasarkan segi kuantitatif dan kualitatif[5].

5. Kebutuhan Luas Area

Tahapan selanjutnya adalah menganalisis jumlah area yang dibutuhkan (Space) untuk departemen. Analisis ini menyangkut kebutuhan area setiap departemen dan juga ketersediaan area secara keseluruhan.

6. Perancangan Layout

Langkah terakhir adalah membuat alternatif layout yang diusulkan sesuai dengan parameter yang diharapkan.

\section{Software Tecnomatix}

Tecnomatix adalah sebuah sistem perangkat lunak yang lengkap untuk menghasilkan lingkungan 3D atau dunia virtual dimana karakter atau manusia di dalamnya dapat melakukan interaksi dengan lingkungan kerja[6]. Fungsi dari software ini antara lain:

1. Membuat dan memvisualisasikan tiruan-tiruan desain.

Software ini memberikan fasilitas tampilan grafis canggih untuk membuat model atau mengimpor data desain ke dunia maya.

2. Menganalisis faktor manusia dalam desain.

Contoh analisis yang dapat dilakukan adalah menentukan jangkauan operator, kesesuaian, kenyamanan, dan penglihatan operator.

3. Mempelajari manusia di tempat kerja yang dirancang Menganalisis kinerja operator sehingga dapat merancang stasiun kerja yang aman, efisien dan produktif.

4. Mengevaluasi operasi perawatan

5. Pelatihan bagi operator

6. Penelitian untuk mengetahui tingkat kelelahan operator

7. Memprediksi gerakan-gerakan operator yang tidak terduga

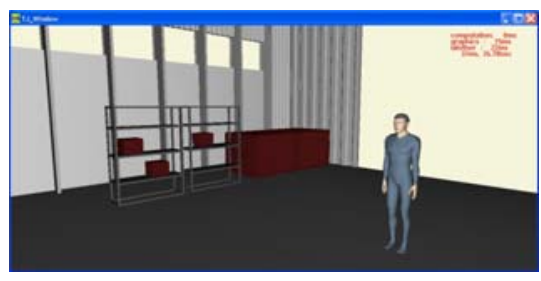

Gambar. 2. Tampilan Interface dari software Tecnomatix

Tidak seperti banyak desain 3D dan sistem visualisasi, 
Tecnomatix bekerja secara native dengan angka yang diartikulasikan. Secara sederhana, Tecnomatix penuh dengan objek yang bergerak, seperti dalam kehidupan nyata. Software ini menyediakan sistem yang sangat kuat untuk pemodelan angka yang diartikulasikan. Fokus dalam pengembangan software ini pada penciptaan model tubuh manusia yang paling akurat.

\section{MEtode Penelitian}

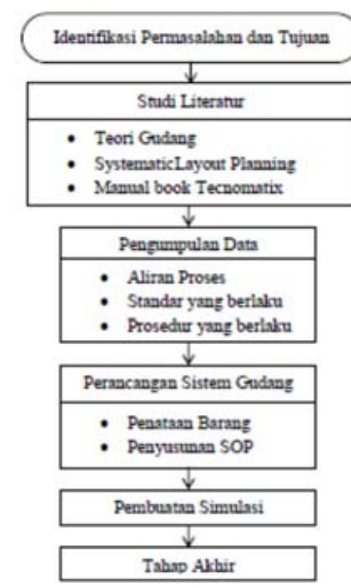

Gambar. 3. Flowchart Metodologi Penelitian

\section{A. Tahap Identifikasi Permasalahan dan Tujuan Penelitian}

Pada tahap ini mengidentifikasi alur proses pada perusahaan distribusi terutama pada proses penerimaan dan pengiriman, menganalisis operator dan peralatan yang terkait serta menentukan permasalahan utama serta menetukan tujuan penelitian.

\section{B. Studi Literatur}

Pada tahap ini mempelajari teori pendukung untuk menyelesaikan persoalan, antara lain teori pergudangan, teori SLP, software Tecnomatix.

\section{Pengumpulan Data}

Data yang dikumpulkan adalah data luas gudang, data alur proses penerimaan dan pengiriman, data operator dan peralatan material handling.

\section{Perancangan Sistem Pergudangan dan Simulasi}

Berdasarkan teori dan kondisi awal dilakukan perancangan layout baru dan disimulasikan dengan software Tecnomatix untuk mendapatkan tingkat efisiensi dari rancangan yang baru.

\section{Pengumpulan Data dan Analisis}

\section{A. Denah Gudang Distributor}

Denah area gudang dibagi menjadi 3 bagian, yaitu area 1 yang terdiri dari area parkir truk, ruang admin dan kasir, dan ruang sales admin.

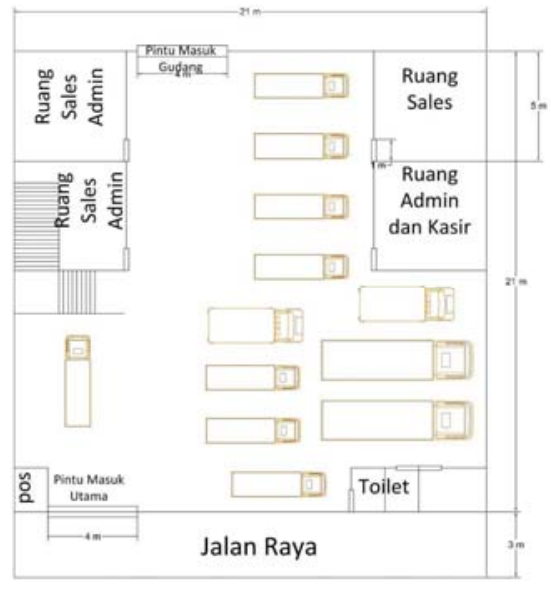

Gambar. 4. Denah Gudang Area 1

Sedangkan area 2 terdiri dari tempat penyimpanan barang, buffer zone, gudang retur, dan tempat penyimpanan berkas. Pada area ini proses penyimpanan barang terjadi.

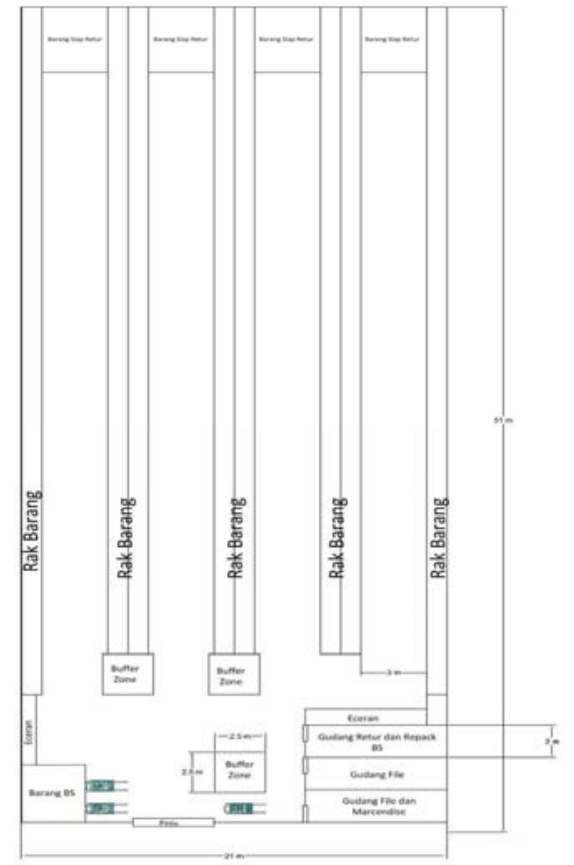

Gambar. 5. Denah Gudang Area 2

Area 3 terletak di lantai 2 yang berisi ruang admin dan manajer operasional serta ruang admin operasional.

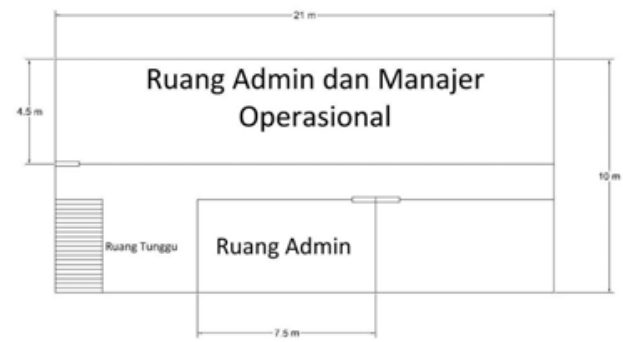

Gambar. 6. Denah Gudang Area 3 


\section{B. Flowchart Proses Penerimaan dan Pengiriman}

Proses utama yang berlangsung dalam perusahaan distribusi adalah proses penerimaan barang dan pengiriman serta pencatatan dokumen. Berikut adalah alur proses penerimaan dan pengiriman yang terjadi.

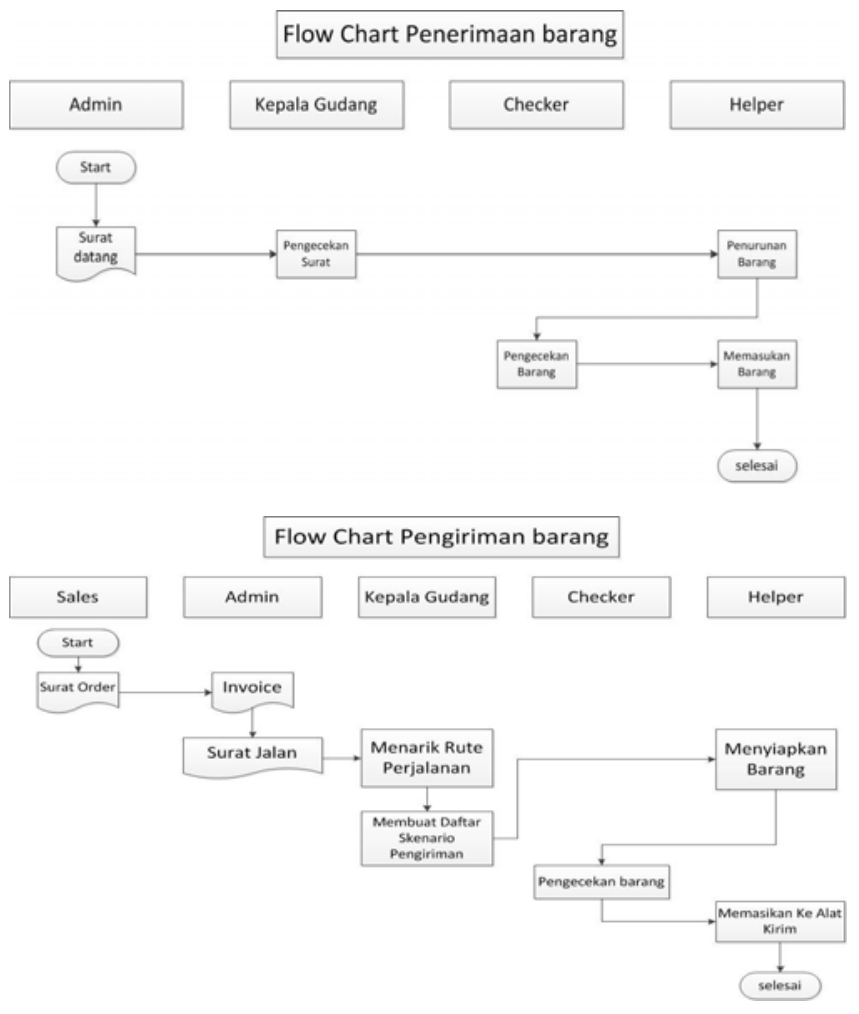

Gambar. 7. Flowchart Proses Penerimaan dan Pengiriman

\section{Permasalahan dalam Proses Distribusi}

Berdasarkan data alur proses penerimaan dan pengiriman serta pengamatan secara langsung pada jalannya proses di area gudang, ditemukan beberapa permasalahan utama yang menjadi penyebab tidak efisiennya proses penerimaan dan pengiriman. Permasalahan-permasalahan tersebut antara lain:

1. Area Buffer Zone yang tidak sesuai

Buffer Zone merupakan area tempat penyimpanan semetara sebelum barang diterima atau dikirim. Proses yang terjadi pada area ini adalah proses pengecekan untuk memastikan produk sesuai. Permasalahan yang dihadapi adalah area buffer zone yang terlalu kecil yaitu 2,5 m x 2,5 m sehingga tidak mencukupi.

2. Jumlah Material Handling yang kurang

Peralatan material handling yang digunakan adalah forklift dan permasalahaannya adalah forktift yang tersedia hanya 1 unit. Dengan terbatasnya jumlah forklift untuk memindahkan barang dari truk ke dalam gudang ataupun dari dalam gudang ke truk menyebabkan terkendalanya proses perpindahan material.

3. Pencatatan barang dan kode barang

Sistem pencatatan yang digunakan oleh perusahaan masih bersifat tradisional dengan manggunakan kertas dan tidak terstandar. Selain itu, peletakan barang pada rak gudang tidak tercatat dengan benar sehingga pada proses pengambilan seringkali dibutuhkan waktu untuk pencarian barang.

\section{Analisis ARC}

Berdasarkan aliran proses yang telah diketahui dilakukan analisis ARC untuk mengetahui tingkat hubungan antar departemen sehingga dapat merancang sistem pergudangan yang lebih efisien. Dari hasil analisis didapatkan bentuk sebagai berikut.

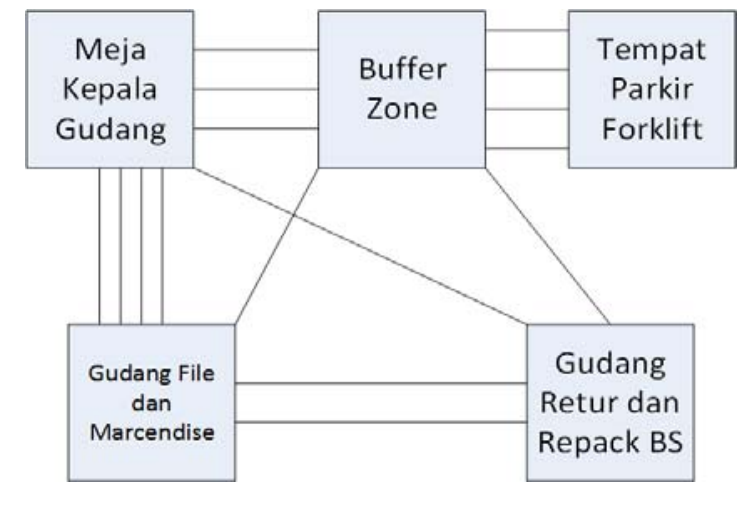

Gambar. 8. Analisis ARC

Dari hasil analisis di atas, diketahui yang memiliki hubungan terkuat adalah meja kepala gudang dam gudang file serta tempat parkir forklift dengan buffer zone. Hal ini menjadi perhatian dalam perbaikan agar proses semakin efisien.

\section{E. Rancangan Perbaikan}

Hasil analisis ARC dan permasalahan yang sudah diketahui menghasilkan rancangan sistem pergudangan yang baru. Perubahan yang dilakukan adalah dengan memperluas area buffer zone menjadi satu kesatuan dan berdekatan dengan area perkir forklift. Selain itu, area kepala gudang dipindahkan dan diberi ruangan khusus sehingga privasi dan keamanan dokumen meningkat. Jumlah peralatan material handling ditambah dari 1 unit menjadi 4 unit. Dan setiap rak diberi pengkodean khusus agar memudahkan dalam hal pencatatan dan pencarian barang. Berikut adalah rancangan sistem pergudangan yang baru pada Gambar 9.

\section{F. Perbaikan Flowchart Proses Penerimaan dan Pengiriman}

Untuk meningkatkan efisiensi proses, perbaikan juga dilakukan pada alur proses penerimaan dan pengiriman. Berikut adalah alur proses yang telah diperbaiki untuk proses penerimaan dan pengiriman pada Gambar 10.

\section{G. Simulasi Perbaikan dan Perhitungan Efisiensi Proses}

Untuk mengukur tingkat efisiensi perbaikan sistem pergudangan digunakan software tecnomatix untuk memproses alur kerja sistem pergudangan. Langkah yang dilakukan adalah dengan merancang area gudang sebelum perbaikan dan setelah perbaikan. Serta memasukkan alur proses kerja pada area sebelum perbaikan dan setelah perbaikan untuk mendapatkan perbedaan waktu proses. 


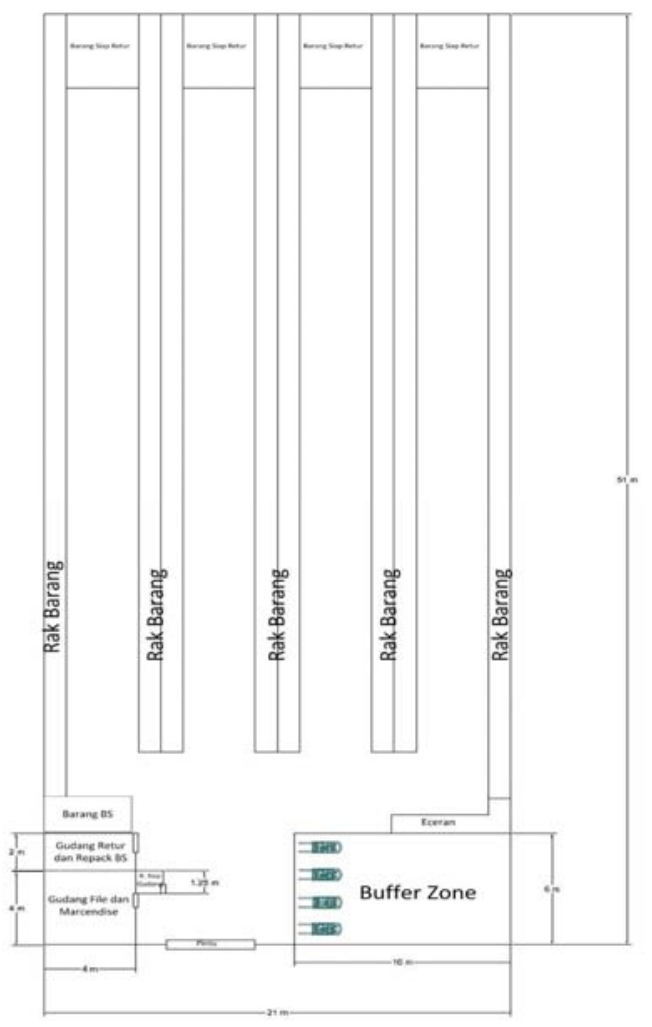

Gambar. 9. Denah Gudang Setelah Perbaikan

Berdasarkan hasil simulasi pada area sebelum perbaikan didapatkan waktu proses untuk proses penerimaan selama 5 menit 32 detik dan waktu proses pengiriman selama 3 menit 42 detik. Sedangkan waktu proses setelah dilakukan perbaikan didapatkan waktu proses untuk proses penerimaan selama 2 menit 53 detik dan waktu proses pengiriman selama 2 menit 7 detik. Dari hasil ini diketahui bahwa dengan melakukan perbaikan sistem pergudangan maka efisiensi waktu proses dapat diperoleh.

\section{KESIMPULAN}

Kesimpulan dari penelitian ini adalah sebagai berikut:

1. Sistem gudang mengalami perubahan, antara lain, buffer zone yang semakin luas dan terpusat sehingga tidak memakan waktu yang lama bagi checker untuk memeriksa barang, meja kepala gudang yang lebih memiliki privasi dan lebih aman, penambahan peralatan material handling, dan perbaikan sistem pengkodean barang.

2. Perbaikan sistem meningkatkan efisiensi proses terlihat dari waktu proses yang semakin cepat. Pada proses penerimaan yang sebelumnya 5 menit 32 detik menjadi

3. 2 menit 53 detik, sedangkan pada proses pengiriman yang sebelumnya 3 menit 42 detik menjadi 2 menit 7 detik.

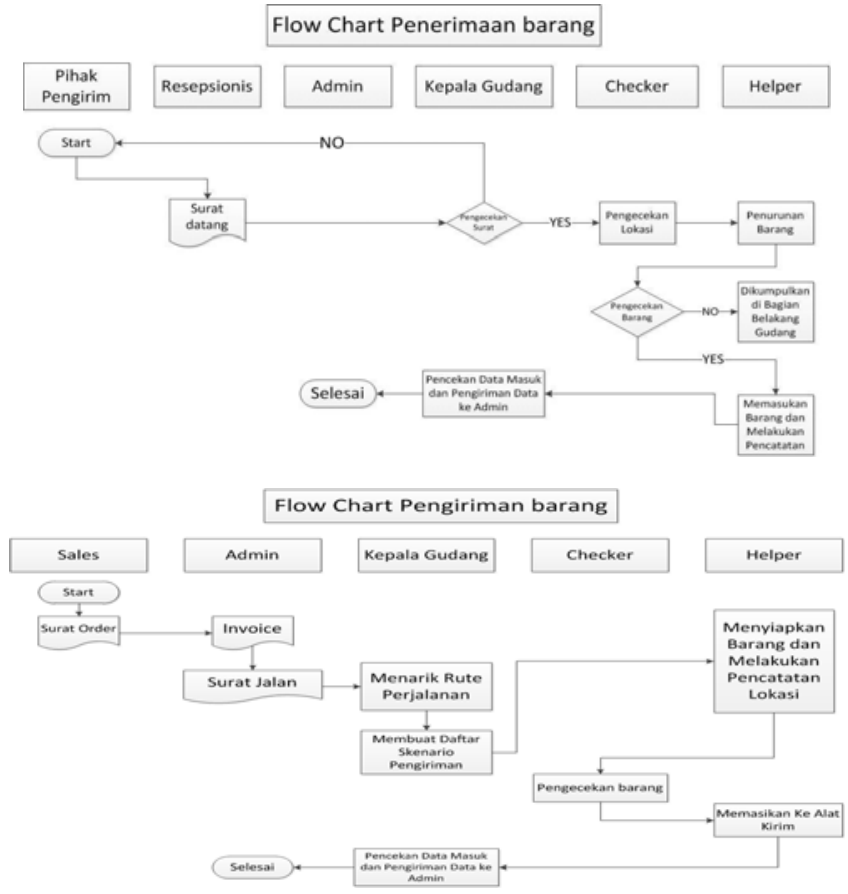

Gambar. 10. Flowchart Penerimaan dan Pengiriman Setelah Perbaikan
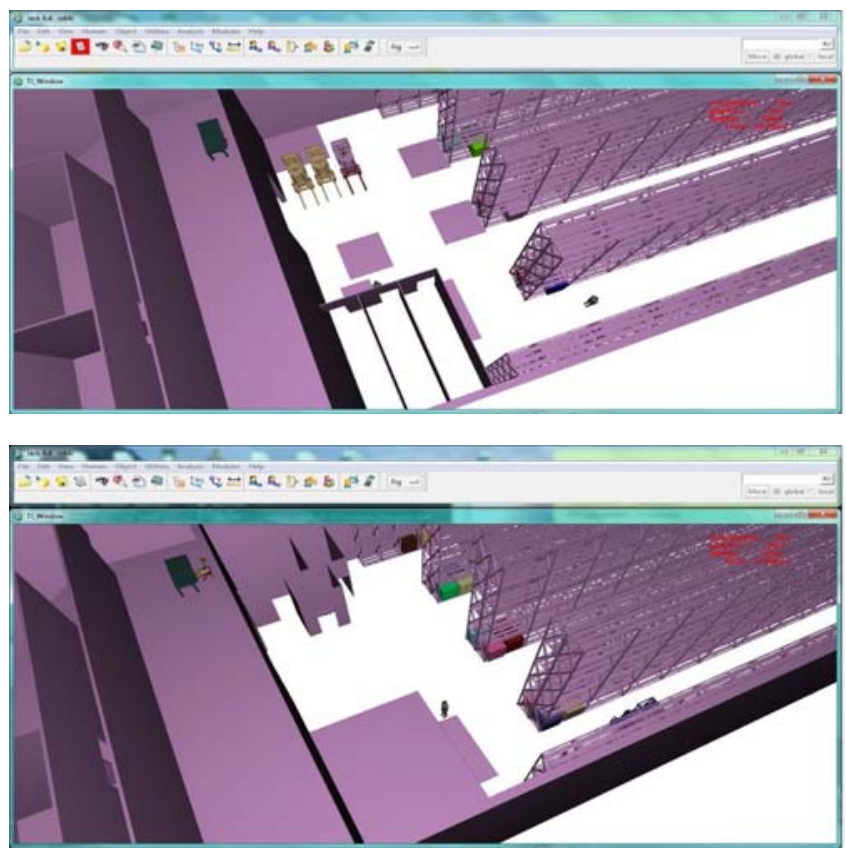

Gambar. 11. Simulasi area kerja sebelum dan sesudah perbaikan.

\section{DAFTAR PUSTAKA}

[1] Apple, M. James. Tataletak Pabrik Dan Pemindahan Bahan. Bandung, Institut Teknologi bandung. 1990.

[2] Tompkins, James. A. Jhon A. White, Yavuz A. Bozer, J. M.A. Tanchoco. Facilities Planning. Third Editions. Wiley \& Sons Incorporeted, John. 1996.

[3] Hadiguna, Rik A. Tata Letak Pabrik. Yogyakarta. Penerbit Andi. 2008.

[4] Heragu, Sesharanga Sunderesh. Facilities Design, Second Edition. Lincoln Universe Inc. 2006.

[5] Wignjosoebroto, Sritomo. Tata Letak Pabrik Dan Pemindahan Bahan.Surabaya, Penerbit Guna Widya. 2009.

[6] Jack Tecnomatix user manual version 8.4. California. PLM Siemens. 2016. 